\title{
EVALUATION OF THE IMPACT OF PHYSIOTHERAPY ON PHYSICAL FITMESS AND RANGES OF MOTION OF SELECTED JOINTS OF ELDERLY WOMEN FROM THE KARKONOSZE UNIVERSITY OF THE THIRD AGE IN JELENIA GÓRA - PRELIMINARY RESULTS
}

\author{
Dorota Cichoń, 1, A, B Zofia Ignasiak, ,, C Iwona Demczyszak,, B \\ Małgorzata Fortuna, ${ }^{1, \mathrm{~B}}$ Małgorzata Milko, ${ }^{1, \mathrm{~B}}$ Tomasz Ignasiak, D \\ ${ }^{1}$ Faculty of Natural Sciences and Technology, Karkonosze College in Jelenia Góra, Poland \\ ${ }^{2}$ Faculty of Physical Education, University School of Physical Education in Wroclaw, Poland \\ ${ }^{3}$ Department and Division of Medical Rehabilitation, Medical University in Wroclaw, Poland \\ ${ }^{\text {A }}$ Study Design; ${ }^{B}$ Data Collection; ${ }^{C}$ Statistical Analysis; ${ }^{D}$ Manuscript Preparation, ${ }^{\mathrm{E}}$ Funds Collection
}

\author{
Address for corpespondence: \\ Dorota Cichoń \\ Karkonosze College in Jelenia Góra \\ Lwówecka 18, 58-503 Jelenia Góra, Poland \\ E-mail: dorota.cichon@wp.pl
}

\begin{abstract}
Ahstract An important aspect of a senior's life is to be able to function independently in his or her own and family surroundings as long as possible, actively participate in social life without economic barriers. Numerous studies show that the quality of life and the biological condition of the elderly alongside nutrition are clearly dominant and have a positive effect on their functional physical fitness. In order to promote physical activity and physiological prevention among the elderly, a physiotherapeutic program was organized under the "Summer Sanatorium of Prevention of the spine pain syndrome", which was attended regularly by a group of senior citizens from the Karkonosze University of the Third Age in Jelenia Góra. The aim of the study was to compare the level of functional physical activity before and after treatment among the participants.

The study was conducted among 20 women aged $60-75$ years, before and after 6 weeks of treatment, which included: gymnastics for prevention of back pain syndromes, relaxation training, full spine massage, TENS electrotherapy and ultrasound in the lumbar and cervical spine. Research included; assessment of functional physical fitness by the Functional Senior Fitness Tests: "stretching behind" and "slope forward", ranges of motion within the selected joints of the spine, upper and lower limbs.

The selected form of physiotherapeutic treatment improves the results obtained after test with the Functional Senior Fitness Test and influences the range of motion in the selected joints, which demonstrates that physical fitness is improved.

Physical activity in the form of general-purpose gymnastics favors higher levels of functional fitness of elderly women, physical therapy and massage improves mood and makes older people more willing to participate in physio preventing programs. The conducted research proves that the developed program was optimal and showed a positive effect on the daily functional fitness of the examined persons.
\end{abstract}

Key WOrld seniors, functional physical fitness, physiotherapy treatments, range of joint mobility 


\section{Introduction}

Among the increasing number of elderly people in society, the key task is to take care of the seniors' quality of life. An increasing number of people over 65 , not only in Europe, will be associated with the health, economic and social consequences for the entire population (Mossakowska, Więcek, Błędowski, 2012). Due to the increasing progress of medicine in the field of diagnostics and treatment, a significant extension of human life is observed, which has a significant impact on increasing the elderly population not only among Polish society but also in Europe and in the entire world. The greater number of seniors and the decreasing number of children and young people caused that European societies exceeded the threshold of demographic aging (Wieczorkowska-Tobis, Kostka, Borowicz, 2011). Demographic forecasts for the next 35 years indicate a steady increase in the number of people aged 65 and over, both women and men, and this process will be much more intensive than before (Błędowski, 2012; Giannakouris, 2008; Kozdroń, 2014). Undoubtedly, an important aspect determining the older people quality of life is their biological condition, which is influenced by economic, social and health factors. The consequences will be associated with the functional efficiency of seniors, translating into health and physical fitness conditioning independence in their own and social environment.

Aging is a natural physiological process that is the last stage of ontogenesis. Late adulthood starts already in middle age and grows over time, and involutional changes taking place in particular organs and systems are irreversible and naturally affect the limitation of people's fitness, even in a situation of independence (Park, 2017; Skalska, 2012; Sygit, 2015).

As a result of the civilization progress, the incidence of morbidity and mortality is still increasing on socalled civilization diseases related to metabolic disorders such as diabetes, obesity, diseases related to cardiorespiratory disorders and deepening deficits in the movement system caused by involutional changes and degenerative processes in the skeletal system and neuromuscular conduction (Mossakowska et al., 2012; Roberts, Philips, Cooper, Gray, Allan, 2017; Skrzek et al., 2015; Sygit, Sygit, Pietrzak, 2016). All these changes are the cause of dysfunction of the musculoskeletal system, reduce the functional efficiency and independence of the elderly person.

The involutional changes affecting the functional efficiency of an elderly person comes first in the muscular system, where the decrease in muscle mass after the age of 35 increases and in people aged 50 and over, the decrease in muscle mass can reach up to 30\% compared to people aged 25 years (Skrzek et al., 2015). With the decline in muscle mass as a result of involutional processes, there is a reduction in muscle strength and disturbances in neuromuscular excitability. The myelin sheaths of the nerves are degenerating, the number of motoneurons in the anterior corneas of the gray matter of the spinal cord is reduced, which significantly limits the neuromuscular transmission. Progressive degenerative and atrophic changes in the nervous system and a decrease in muscle tone and weakness of reflexes are the cause of balance and body postural instability disorders (Ignasiak et al., 2017; Kubica, 2015; Park, 2017).

One of the key elements of dignified aging is the ability to function independently and secure one's own needs enabling self-service in the basic activities of everyday life and self-fulfillment in the family and society. These activities are significantly influenced by the range of suppleness, mobility of the joints, muscular strength and sense of balance, which are limited as time passes. 
There is still no consensus what treatments are the most beneficial in the slowdown of involution processes that occur as a result of the aging of the human body and at the same time affect the functional efficiency of older people. There are various forms of movement available for seniors, to which each of them reacts individually.

Numerous studies clearly prove that various forms of physical activity, appropriately selected, have a positive effect on the functional status of elderly people. For this reason, it is important to convince seniors to use certain forms of physical activity, by carrying out preventive activities in gerontology. An example of such activities may be disseminated general improvement programs among older people (Adamo, Susan, Goldberg, 2015; Kostka, Kostka, 2011; Kozdroń, 2014; Ossowski, Wawryniku, Česnaitiene, 2015; Wesołowska 2016).

Changing environmental conditions, dynamic urbanization require optimal programs and therapies that will be available and encouraging for older people. It will allow to achieve the goal of maintaining physical fitness for as long as possible, giving them the opportunity to perform everyday tasks on their own and optimally functioning in present-day reality (Ignasiak, Nowak, Domaradzki, Falkengerg, 2013; Osiński 2013; Wizner, Skalska, Klich-Rączka, Piotrowicz, Grodzki, 2012). For seniors, undoubtedly the most important factor is good health, which translates into quality of life and functional independence. Therefore, general improvement programs containing elements of physioprophylaxis can be, along with other forms of adaptive physical activity, more motivating for these people (Nowocień, 2012; Roberts et al., 2017).

The aim of the study was to evaluate the effectiveness of 6 weeks therapy to improve flexibility and increasing functional physical fitness in older women, students of the Karkonoski University of the Third Age in Jelenia Góra.

\section{Material and methods}

The research was carried out in the second half of 2015. Participants were the students of the Karkonoski University of the Third Age at the Karkonosze State College in Jelenia Góra. The research was carried out twice by the same team of employees of the Karkonosze State College and the author of the work.

The first tests took place in mid-August 2015 before the start of therapy, the second study was repeated in the first week of October 2015 after completing the planned treatments. The research material were the results of measurements obtained before and after the therapy among the same group of women of 20 people in the 60-75 age group. The average age of the surveyed women was 67 years.

Conditions for inclusion in tests:

- sex and age - women between 60 and 75 years of age,

- subjectively feel of good health,

- written consent of the primary care physician for the patient's participation in the project and no contraindications to perform certain physiotherapy treatments and the planned scope of research,

- signing a voluntary consent to participate in research. Each participant was informed about the purpose of the research, the type and method of conducting them and the possibility of giving up treatments and examinations without giving reasons.

Physiotherapy lasted 6 weeks, treatments were performed three times a week with an even distribution on Mondays, Wednesdays and Fridays, each time included the following program, the same for each participant:

- general group gymnastics aimed at the prevention of spinal pain syndrome, which lasted 45 minutes,

- relaxation break lasting 10-15 minutes,

- classical massage of the back muscles - 25 minutes, 
- L-TENS electrotherapy treatment lasting 20 minutes, for the first three weeks applied to the lumbosacral region of the spine, for the next three weeks, applied to the cervical-thoracic segment of the spine,

- treatment in the field of sonotherapy - ultrasound (about 6 minutes), for the first three weeks applied to the region of the lumbar-sacral spine, for the next three weeks applied to the region of the cervical-thoracic segment of the spine.

The treatments were carried out under the supervision of a physiotherapist, author of work in kinesiotherapy, physiotherapy and massage clinics at the Karkonosze State College, equipped with appropriate specialist equipment.

The applied research methods included:

1. Evaluation of flexibility within the upper and lower body made using the selected set of functional tests from the Functional Senior Fitness Test battery (Rikli, Jones, 2001): "stretching behind" and "slope forward".

2. Measurements of motion ranges within selected upper limb and lower limb joints: brachial, ulnar, iliac, were made using a goniometer in accordance with the accepted test methods (Skolimowski, 2009). For the purposes of the research, the ranges of active movements in the joints performed by the strength of the examined muscles were measured. All measurements were started from the zero position. The examined woman after take the starting position for the measurement in a given joint do the maximum movement. The result was given in degrees and recorded in accordance with the SFTR method.

3. Assessment of mobility in the lumbar spine. Meausermentswere made using a centimeter tape with an accuracy of $0.5 \mathrm{~cm}$ according to the Schober test (Skolimowski, 2009).

The project was positively evaluated by the Senate Committee for Ethics of Scientific Research at the University of Physical Education in Wrocław (resolution number on the opinion on the project of the cognitive experiment 12/2016).

\section{Methods of statistical elaboration}

In the elaboration of the collected material, the following were used:

1. Descriptive statistics methods: arithmetic mean ( $\mathrm{x}$ ) and standard aberration (s) before and after therapy.

2. The significance of the mean differences between the pre- and post-therapy tests was assessed by the test t-Student for dependent groups.

The material distribution was normal. In all tests, $p<0.05$ was considered statistically significant.

\section{Results}

The result of the "stretching behind" test evaluating the flexibility of the upper body turned out more advantageous by almost $3 \mathrm{~cm}$ after treatment. The difference between the pre-and post-therapy tests was statistically significant. After analyzing the test - a "slippery slope" assessing the flexibility and range of mobility in the joints of the lower limbs and the spine, an average increase in the mobility of $5.5 \mathrm{~cm}$ was noted. The difference between the pre- and post-therapy tests was statistically significant (Table 1, Figure 1). Positive changes were observed after the therapy ended and the analysis of the tests evaluating the flexibility of the upper and lower body was carried out. 
Tahle 1. Statistical characteristics and assessment of the differences between the means of functional physical fitness in terms of elasticity of upper and lower body before and after 6-week therapy (Student's t-test for dependent tests)

\begin{tabular}{lccccccc}
\hline \multicolumn{1}{c}{ Variable } & Before & $\mathrm{s}$ & After & $\mathrm{s}$ & $\begin{array}{c}\text { Before/after } \\
\mathrm{d}\end{array}$ & Student's test & $\mathrm{p}<0.05$ \\
\hline "Stretching behind" & -6.40 & 7.47 & -3.53 & 6.53 & -2.88 & 2.6800 & 0.0074 \\
"Slope forward" & 1.35 & 5.95 & 6.43 & 6.51 & 5.53 & 4.4095 & 0.0002 \\
\hline
\end{tabular}

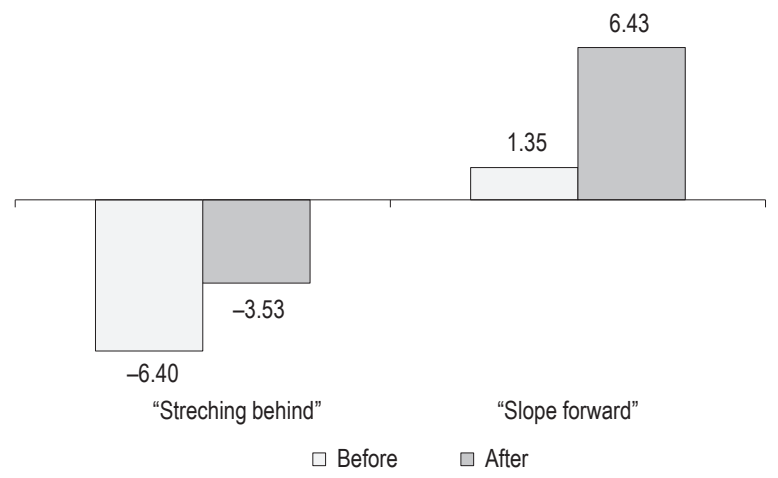

Figure 1. The average values of flexibility within the upper and lower body before and after therapy among the surveyed women $(\mathrm{cm})$

As a result of involutional changes occurring in various systems and organs in the aging process of the organism there is a limitation of the mobility within the joints of the upper limbs, lower limbs and torso, which affects the functional efficiency and the biological condition of an elderly person. In order to check the effectiveness of the treatment effect, we examined the ranges of mobility in the joints: shoulder, ulnar and hip joints as well as the extent of the forward flexion movement in the lumbar spine (Table 2, Figures 2-6).

In the shoulder joint and the shoulder girdle, the ranges of motion in the sagittal plane were measured: the movement of the back and the forebending in the right and left shoulder joint. In the study prior to the program, the mean extent of the retraction movement in the right shoulder was $54^{\circ}$, after therapy it was $60^{\circ}$, in the left shoulder joint - it was $57^{\circ}$ before therapy, after therapy $62^{\circ}$. The analysis of the data shows that the extent of the torsional movement increased by $6^{\circ}$ in the right shoulder and by $5^{\circ}$ in the left shoulder, and the difference was statistically significant (Table 2, Figure 2). The average range of the anterior movement in the right shoulder increased statistically significantly after the therapy by almost $3^{\circ}$, in the left shoulder - about $4^{\circ}$ (Table 2 , Figure 3 ). It can be concluded that the total range of motion in the sagittal plane, adding up the positive effects of the movement of the back and the forebrain, increased on average by $9^{\circ}$ in the right and left shoulder after 6 weeks of therapy. 
Table 2. Statistical characteristics and evaluation of differences between the average of motion ranges in selected joints before and after 6 weeks of therapy in the studied women

\begin{tabular}{|c|c|c|c|c|c|c|c|}
\hline Variable & Before & s & After & s & $\begin{array}{c}\text { Before/after } \\
d\end{array}$ & Student's test & $p<0.05$ \\
\hline Shoulder joint $\mathrm{P}$ backbone $\left(^{\circ}\right)$ & 53.75 & 10.99 & 59.75 & 8.66 & -6.00 & 4.5418 & 0.0001 \\
\hline Shoulder joint $\mathrm{P}$ pre-bending $\left({ }^{\circ}\right)$ & 167.25 & 8.65 & 170.00 & 6.69 & -2.75 & 2.9039 & 0.0045 \\
\hline Shoulder joint $L$ back $\left({ }^{\circ}\right)$ & 57.00 & 9.92 & 61.50 & 9.05 & -4.50 & 3.2432 & 0.0021 \\
\hline Shoulder joint $L$ anterior thrust $\left({ }^{\circ}\right)$ & 167.50 & 7.34 & 170.25 & 6.17 & -3.75 & 3.2065 & 0.0011 \\
\hline Elbow joint $\mathrm{P}$ bend $\left({ }^{\circ}\right)$ & 142.00 & 6.57 & 145.00 & 5.38 & -3.00 & 3.1864 & 0.0024 \\
\hline Elbow joint $L$ bend $\left(^{\circ}\right)$ & 140.25 & 8.18 & 144.75 & 7.16 & -4.50 & 4.9780 & 0.0000 \\
\hline Hip joint $\mathrm{P}$ bend $\left(^{\circ}\right)$ & 110.00 & 11.81 & 119.50 & 10.87 & -9.50 & 5.1453 & 0.0000 \\
\hline Hip joint $L$ bend $\left({ }^{\circ}\right)$ & 108.00 & 10.93 & 119.00 & 10.07 & -11.00 & 5.9593 & 0.0000 \\
\hline Lumbar spine joints $(\mathrm{cm})$ & 5.55 & 1.16 & 6.15 & 0.84 & -0.60 & 3.2505 & 0.0021 \\
\hline
\end{tabular}

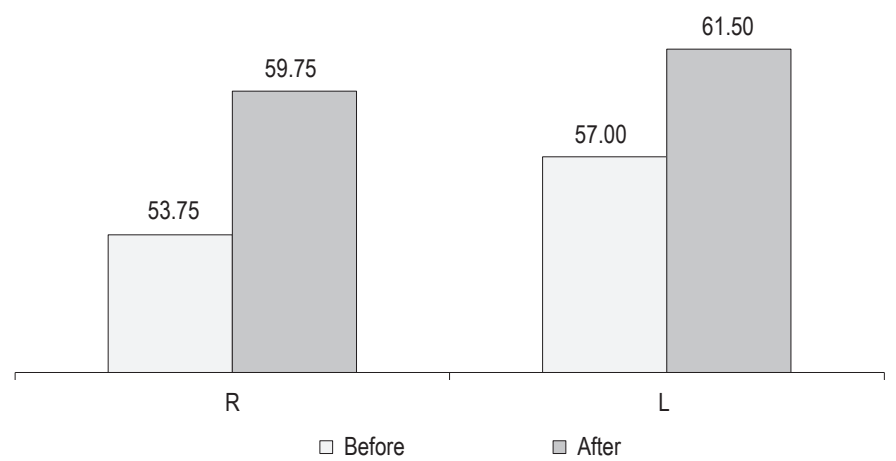

Figure 2. The mean values of the range of movement in the right $(R)$ and left $(L)$ shoulder joint before and after the therapy among the examined women $\left({ }^{\circ}\right)$

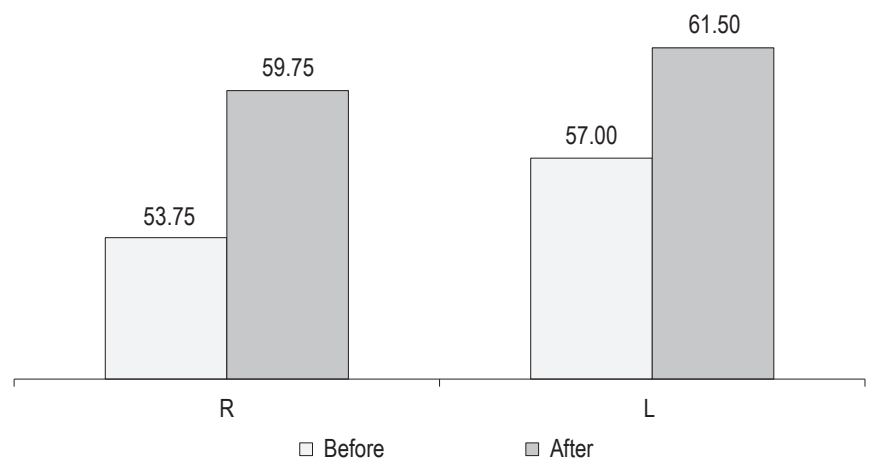

Figure 3. The mean values of the anterior deflection range in the right $(R)$ and left $(L)$ shoulder joint before and after therapy among the studied women $\left(^{\circ}\right)$ 
An important factor that is important for self-service and functional ability in everyday life for an older person is mobility in the elbow joint.

In the research, the extent of flexion movement in the right and left ulnar joints was measured, which before the therapy was on average $142^{\circ}$ - in the right elbow joint, $140^{\circ}$ - in the left elbow joint. After therapy, it increased by $3^{\circ}$ in the right elbow joint and by $4.5^{\circ}$ in the left elbow (Table 2, Figure 4).

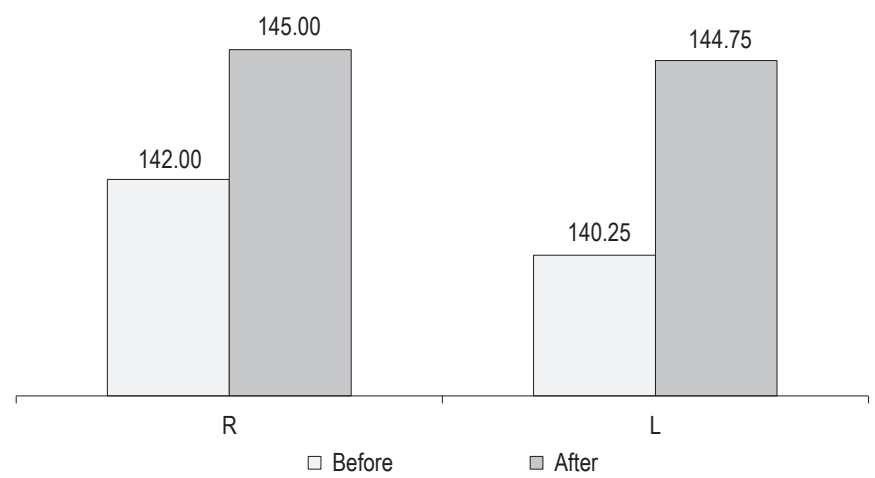

Figure 4. The average values of the movement range of flexion in the right $(R)$ and left $(L)$ elbow joint before and after therapy among the examined women $\left(^{\circ}\right)$

Obtained results of measurements within the upper limb are statistically significant and testify to the positive effects of the appropriate treatments.

Retaining mobility in the joints of the lower limbs is necessary to locomotion and determine its quality and functionality. An important aspect in the possibility of walking and sitting are the sagittal movements of the hip and knee joints. In the lower limb, the movements of the left and right hip flexion were examined. The range of flexion movement in the right hip joint was improved by an average of $9.5^{\circ}$ and by $11^{\circ}$ in the left hip joint (Table 2, Figure 5).

All measured movements within the upper limb and lower limb, both before and after the therapy, are within the range of standards for a given age group (Skolimowski, 2009).

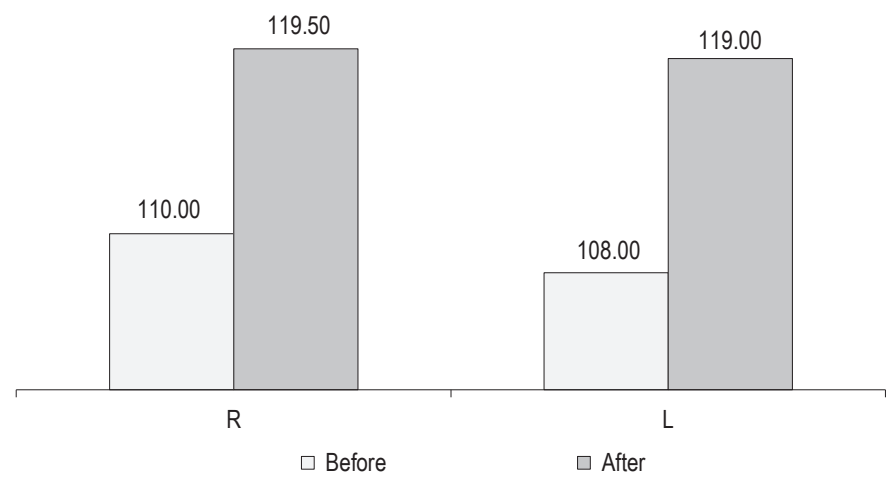

Figur 5 . The average values of the movement range of flexion in the right $(R)$ and left $(L)$ hip joint before and after therapy among the examined women $\left({ }^{\circ}\right)$ 


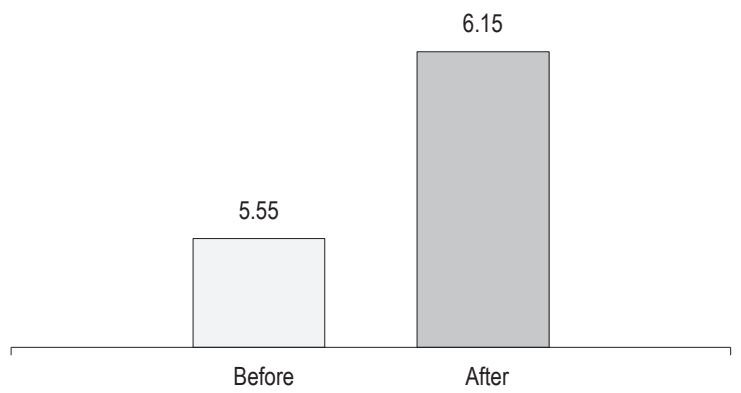

Figure $\boldsymbol{b}$. The average values of the extent of flexion movement of the front lumbar spine before and after therapy among the examined women $(\mathrm{cm})$

One of the most important problems affecting the functional efficiency of the elderly are the deepening deficits in the movement system associated with the restriction of mobility within the spinal joints (Szewczyk, 2016). The mean values of the difference of results obtained between the extension and then the bending of the spine examined before and after the 6-week treatment were taken for analysis. Before therapy, the difference between extension and flexion in the sagittal plane of the lumbar spine was $5.6 \mathrm{~cm}$, after therapy - over $6 \mathrm{~cm}$. After therapy, it was noticed that flexibility improved within the lumbar spine, increasing its elasticity by $0.6 \mathrm{~cm}$. The difference between measurements shows statistical significance (Table 2, Figure 6).

\section{Disculusion}

With age, all functions of the human body gradually deteriorate. Changes occurring in particular systems and organs affect the way of moving and performing everyday activities. Adamo et al. (2015), Sygit (2015) draw attention to the fact that, to a large extent, the dynamics of involutional processes in an adult person is affected by physical activity carried out by him both in everyday life and at work. Systematically practiced physical activity by older people determines efficiency, independence and resourcefulness in everyday life, significantly affects the slowing down of degenerative processes in particular systems, and especially in the musculoskeletal system, determines well-being and quality of life. In order for physical activity to slow down the regression phenomena of seniors' motor skills, it should be properly planned and dispensed taking into account the physical condition, subjective health and functional state of the elderly (Roberts et al., 2017; Skrzek et al., 2015).

Duda (2008) and Kozdron (2014) draw attention to the low interest in recreation among older people, which results mainly from ignorance or insufficient information on the preventive role of physical activity. According to Kozdroń (2014) in Poland $50-70 \%$ of the population admit to a passive lifestyle, depending on age, and only $12 \%$ of people aged $60+$ take up physical activity at least once a week. The necessity of practicing systematic and regular physical activity among seniors in order to preserve the biological condition was also noticed by Duda (2008). The author presents the results of research on the activity and physical fitness of people aged 60-69. Subjective assessment of own activity and physical fitness by participants in the studies was placed at the medium level. The obtained results indicated a greater activity of women than men towards the regular practice of sports and recreation (39\%). In most women, the author noted the average level of endurance. The most often mentioned form of physical activity among the subjects was walking. In addition, women preferred gymnastics (49\%). According to 
the author, physical activity should be used systematically, even permanently applied in the lifestyle of older people in particular. Also, the offer addressed to seniors should include a wide range of opportunities for active and healthy spending of free time.

An important issue is the promotion of a healthy lifestyle among older people, in other words, actions towards healthy aging. At the same time, many authors indicate beneficial results in the field of improving functional fitness and biological condition. through the application of a comprehensive physiotherapy (Hawrylak et al., 2010; Ignasiak, Ziółkowska-Łajp, 2012; Szewczyk, 2016).

Ignasiak, Ziółkowska-Łajp (2012) draw attention to the beneficial effect of sanatorium comprehensive physiotherapeutic treatment on functional fitness, health and better well-being among from rural areas. The author's 6-week comprehensive therapy carried out as part of the physiotherapeutic program "Summer Sanatorium of Spinal Pain Relief Therapy", in which a group of seniors from the Karkonoski University of the Third Age in Jelenia Góra systematically participated, positively influenced the improvement of physical fitness. Authors Ignasiak, Ziółkowska-Łajp (2012), however, suggest that in order to maintain the positive effects of the functional state, obtained during the rehabilitation period, it would be necessary to multiply the frequency of sanatorium stays for women from rural areas. Residents of cities are definitely more likely to use spa treatment.

The conducted 6 weeks author's therapy program improve the ranges of mobility in the examined joints of the upper limbs and lower limbs. The extent of the spinal flexion in the lumbar region has improved. The flexibility in the upper and lower body after the treatments has increased. A similar assessment of therapeutic effects was made by Szewczyk (2016) in his work proving that comprehensive therapy used in sanatorium and outpatient treatment brought benefits in the area of increasing physical activity, improving mobility and reducing pain in the lower section spine. The author, however, convinces that spa treatment has more beneficial effect on the progress of rehabilitation than outpatient treatment thanks to the support of traditional physiotherapeutic treatment by natural methods used in spa sanatoriums, such as mud treatments, salt baths and the advantages of the spa environment.

Similar conclusions regarding the continuation of functional improvement after the stay on the rehabilitation in the sanatorium and carrying out tests controlling the effects of therapy presented by Hawrylak et al. (2010). The authors point out that the three-week period of rehabilitation has positively influenced the improvement of all assessed functional parameters in patients with degenerative changes of the lower spine (in the 53-71 age group). However, therapy should be continued to preserve its effects.

Positive results obtained after the 6-week therapeutic program point the authors of the project that the program will be extended to a larger group of seniors, both women and men, which will enable further research.

The authors confirm that all kinds of therapies affecting the functional efficiency of older people will not bring long-lasting results if they are not continued and repeated.

\section{Conclusions}

The therapy improve flexibility in the upper and lower body of older women by increasing the ranges of mobility within selected joints of the upper and lower limbs and joints of the lumbar spine. This is important in many selfservice and daily activities, allowing to maintain functional independence not only in everyday life.

Older people willingly participate in the form of related physical activity with elements of physioprophylaxis, for them health and functional efficiency become the most important value in their lives. 
It should be assumed that properly selected forms of physical activity and physiotherapeutic programs for the elderly will allow them to maintain a good biological condition and function independently in the social and family environment.

Optimal biological condition of seniors and prolonged independence will have beneficial economic effects significantly reducing the state's financial resources directed to the medical care of seniors. Therefore, programs of systematic classes in physical activity combined with physioprophylaxis should be developed and implemented. They will help maintain optimal fitness of the body and a higher quality of life for older people.

\section{References}

Adamo, D.E., Susan, A.T., Goldberg, A. (2015). Age and Task Differences in Functional Fitness in Older Woman: Comparisons with Senior Fitness Test Normative and Criterion-reference Data. Journal of Ageing and Physical Acttivity, 23, 47-54.

Błędowski, P. (2012). Starzenie się jako problem społeczny. Perspektywy demograficzne starzenia się ludności Polski do roku 2035. In: M. Mossakowska, A. Więcek, P. Błędowski Polsenior. Aspekty medyczne, psychologiczne, socjologiczne i ekonomiczne starzenia się ludzi w Polsce (pp. 11-23). Poznań: Termedia Wydawnictwo Medyczne.

Duda, B. (2008). Aktywność i sprawność fizyczna osób w wieku 60-69 lat. Medycyna Sportowa, 6 (6), 24, 379-384.

Giannakouris, K. (2008). Ageing characterises the demographic perspectives of the European societies. Eurostat. European Commission. Retrieved from: http://ec.europa.eu/eurostat.

Hawrylak, A., Skolimowska, B., Barczyk, K., Boerner, E., Hawrylak, A., Kurczyk, M., Ratajczak, B. (2010). Ocena wybranych parametrów czynnościowych u pacjentów ze zmianami zwyrodnieniowymi dolnego odcinka kręgosłupa leczonych w warunkach sanatoryjnych. Acta Bio-Optica et Informatica Medica, 1 (16), 25-27.

Ignasiak, T., Ziółkowska-Łajp, E. (2012). Ocena kierunku zmian zakresu ruchomości stawów w wyniku leczenia sanatoryjnego u kobiet wiejskich z dolegliwościami bólowymi narządu ruchu. Medycyna Ogólna i Nauki o Zdrowiu, 18 (2), 85-91.

Ignasiak, Z., Nowak, A., Domaradzki, J., Falkenberg, J. (2013). Wpływ 8-tygodniowego treningu Nordic Walking na wybrane parametry somatyczne i zmiany zakresów ruchów w stawach starszych kobiet. Antropomotoryka, 23 (62), 39-46.

Ignasiak, Z., Sławińska, T., Skrzek, A., Rożek, K., Kozieł, S., Posłuszny, P., Malina, R.M. (2017). Functional capacities of Polish adults of 60-87 years and risk of losing functional independence. Annals of Human Biology, 44 (6), 502-509.

Kostka, T., Kostka, J. (2011). Trening zdrowotny osób starszych. In: K. Wieczorkowska-Tobis, T. Kostka, A.M. Borowicz, Fizjoterapia w geriatrii (pp. 31-44). Warszawa: Wydawnictwo Lekarskie PZWL.

Kozdroń, E. (2014). Aktywność rekreacyjna w procesie pomyślnego starzenia się. Zeszyty Naukowe WSKFiT, 9, 75-84.

Kubica, J.L. (2015). Assessment of correlation of risk of falls and physical fitness and occurrence of falls among private nursing home residents. Hygeia Public Health, 50 (1), 177-182.

Mossakowska, M., Więcek, A., Błędowski, P. (2012). Polsenior. Aspekty medyczne, psychologiczne, socjologiczne i ekonomiczne starzenia się ludzi w Polsce. Poznań: Termedia Wydawnictwo Medyczne.

Nowocień, J. (2012). Wokół problematyki pozytywnego starzenia się człowieka. In: J. Nowocień, K. Zuchora (eds.), Aktywność fizyczna i społeczna osób trzeciego wieku (pp.108-126). Warszawa: AWF.

Osiński, W. (2013). Gerokinezjologia. Nauka i praktyka aktywności fizycznej w wieku starszym. Warszawa: Wydawnictwo Lekarskie PZWL.

Ossowski, Z., Wawryniku, M., Česnaitiene, V.J. (2015). Influence of nordic walking training on static and dynamic body balance among the elderly. Baltic Journal of Health and Physical Activity, 7 (1), 72-80.

Park, S.H. (2017). Tools for Assessing Fall Risk in the Elderly: A Systematic Review and Meta-Analysis. Aging Clinical and Experimental Research, 1-16.

Rikli, R., Jones, C.J. (2001). Senior Fitness Test Manual. Human Kinetics, Champaign.

Roberts, C.E., Phillips, L.H., Cooper, C.L., Gray, S., Allan, J.L. (2017). Effect of Different Types of Physical Activity on Activities of Daily Living in Older Adults: Systematic Review and Meta-Analysis. Journal of Aging and Physical Activity, 25 (4), 653-670.

Skalska, A. (2012). Ograniczenie sprawności funkcjonalnej osób w podeszłym wieku. Zdrowie Publiczne i Zarządzanie, 1/2011, 50-59.

Skolimowski, T. (ed.) (2009). Badanie czynnościowe narządu ruchu w fizjoterapii. Wrocław: Wydawnictwo Akademia Wychowania Fizycznego. 
Skrzek, A., Ignasiak, Z., Sławińska, T., Domaradzki, J., Fugiel, J., Sebastjan, A., Rożek, K. (2015). Structural and functional markers of health depending on lifestyle in elderly women from Poland. Journal of Clinical Interventions in Aging, 10, 781-793.

Sygit, K. (2015). Fundamental significance of physical activity for seniors' health. Central European Journal of Sport Sciences and Medicine, 4, 53-59.

Sygit, K., Sygit, M., Pietrzak, M. (2016). Physical activity as prevention of chronic illnesses in seniors. Central European Journal of Sport Sciences and Medicine, 14 (2), 79-86.

Szewczyk, J. (2016). Ocena i porównanie skuteczności zabiegów rehabilitacyjnych wykonywanych w warunkach sanatoryjnych i ambulatoryjnych w dolegliwościach bólowych dolnego odcinka kręgosłupa. Doniesienia wstępne. Ortopedia Traumatologia Rehabilitacja, Medsportpress, 18 (4), 349-357.

Wesołowska, J. (2016). Nowe możliwości aktywności ruchowej dla seniorów-parki rehabilitacyjne. Rehabilitacja w Praktyce, 3, 6-11.

Wieczorkowska-Tobis, K., Kostka, T., Borowicz, A.M. (2011). Fizjoterapia w geriatrii. Warszawa: Wydawnictwo Lekarskie PZWL.

Wizner, B., Skalska, A., Klich-Rączka, A., Piotrowicz, K., Grodzicki, T. (2012). Ocena stanu funkcjonalnego u osób w starszym wieku. In: M. Mossakowska, A. Więcek, P. Błędowski (eds.), Polsenior. Aspekty medyczne, psychologiczne, socjologiczne i ekonomiczne starzenia się ludzi w Polsce (pp. 81-94). Poznań: Termedia Wydawnictwo Medyczne.

Cite this anticle aS: Cichoń, D., Ignasiak, Z., Demczyszak, I., Fortuna, M., Milko, M., Ignasiak, T. (2018). Evaluation of the Impact of Physiotherapy on Physical Fitness and Ranges of Motion of Selected Joints of Elderly Women from the Karkonosze University of the Third Age in Jelenia Góra - Preliminary Results. Central European Journal of Sport Sciences and Medicine, 4 (24), 65-75. DOI: 10.18276/cej.2018.4-07. 